\title{
Bank Transparency and Risk Taking: Empirical Evidence from Tunisia
}

\author{
Raoudha Dhouibi ${ }^{1}$, Abir Mabrouk $^{2} \&$ Emna Rouetbi $^{3}$ \\ ${ }^{1}$ Assistant Professor, Faculté des Sciences Juridiques, économiques et de Gestion de Jendouba, Jendouba, Tunisia \\ ${ }^{2}$ Assistant Professor, Institut Supérieur de Commerce et de Comptabilité de Bizerte, Bizerte, Tunisia \\ ${ }^{3}$ Assistant Professor, Institut Supérieur de Finance et de Fiscalité de Sousse, Sousse, Tunisia \\ Correspondance: Raoudha Dhouibi, Faculté des Sciences Juridiques, économiques et de Gestion de Jendouba, \\ Jendouba, Tunisia, Avenue de 1'U.M.A, 8189, Tunisia. Tel: 216-24-454-722. E-mail: raoudha.dhouibi@isg.rnu.tn
}

Received: February 17, 2016

Accepted: March 24, 2016

Online Published: April 25, 2016

doi:10.5539/ijef.v8n5p111

URL: http://dx.doi.org/10.5539/ijef.v8n5p111

\begin{abstract}
An important unresolved issue in finance is the extent to which bank transparency promotes or undermines banking risk-taking. Financial accounting information is an essential component of transparency and a necessary condition for market discipline. This latter can be conceptualized as a market-based incentive scheme with which investors in banking securities penalize banks for greater risk-taking by asking for higher returns on their investments. However, in developing countries, where financial markets are insufficiently developed, the role of market discipline in limiting banks' risk-taking may be restricted.

This paper examines the impact of transparency, as measured by voluntary disclosure of financial information, on the fragility of Tunisian banks. This study is motivated by the decision of the Central Bank of Tunisia to implement the directives of the second Basel Accord to improve the soundness and the safety of the Tunisian banking system. We examine a sample of ten Tunisian banks listed on the Stock Exchange of Tunis over the period 2000-2011. The results show that transparency has no effect on Tunisian banks' risk-taking. Similarly, the results indicate that the capital adequacy ratio has no effect on the non-performing loans rate. These results may undermine the effectiveness of the guidelines of the Basel Committee agreements to reduce risk-taking by Tunisian banks.
\end{abstract}

Keywords: transparency, capital adequacy ratio, bank risk-taking, Tunisian banking sector

\section{Introduction}

Given the complexity of the environment in which banks operate and the sophistication of their activities, the second Basel Accord has suggested that banks use their proper internal models to determine the amount of capital that would allow them to cover the risks in their activities. However, this additional responsibility increases the possibility that banks will manipulate information reported to regulators. Such a reporting behavior attests for the importance of promoting bank transparency in order to support market discipline.

Bliss and Flannery (2002) indicate that banking information communicated to the market is central to boost transparency and allows for a better supervision and impact on market actors. However, the Basel Committee admits that minimum standards of financial communication do not necessarily ensure a sufficient level of transparency. Therefore, banks are encouraged to go beyond these minimal standards and to voluntarily disclose every information considered important for market operators.

The purpose of this study is to examine the effects of Tunisian banks' financial information voluntary disclosure on the solidity of these firms. Our interest consists in checking whether the second Basel accord principles could act on risk-taking behavior of banks operating in a developing country, knowing that these principles have been conceived to meet the needs of banks operating in developed countries (The G10 countries).

We are particularly interested in the Tunisian banking sector because, like all developing countries, financing of the Tunisian economy relies essentially on banking institutions. However, when these latter show signs of fragility, they may negatively affect the entire economy and households' welfare.

The rest of this study is structured as follows. The first section examines the relationship between bank 
transparency and risk-taking. The second section proposes other factors considered significant by the literature to explain bank risk level. Finally, we present the methodology; the data, the variables and we interpret the results.

\section{Transparency and Protection Against Credit Risk: Literature Review}

Bushman (2015) defines bank transparency as: "Bank transparency can be defined as the availability to outside stakeholders of relevant, reliable information about the periodic performance, financial position, business model, governance, and risks of banks." This author pointed out that financial accounting information is an essential component of transparency.

The Basel Committee emphasized that adequate financial communication is an important precondition for market discipline. To improve banking institutions' market discipline and make it more efficient, the third pillar of the second Basel Accord posits that banks should be sufficiently transparent. Thus, banks should provide rich and relevant information to investors about the nature of transactions as well as the results obtained. The Basel Committee devotes a particular importance to market discipline because banking institutions, like all other companies, are supervised by their consumers and investors who care about their securities.

If financial communication is good quality, it should contribute to avoiding banking problems. Financial communication can encourage banks to act prudently and efficiently because banking managers know that their activities and their exposure to risks will be clearly seen by market operators. The fear of market participants' reactions encourages bankers to improve their risk management and internal control practices. Market discipline based on adequate financial communication could efficiently complete the efforts of the control authorities in favor of strong systems and sound practices of risk management.

In fact, market discipline may fail when investors have no knowledge of the bank's risk profile or more when disclosed information is limited. In this context, Hamalainen et al. (2005) highlighted the role of transparency in the effectiveness of market discipline effect on banking behavior. These authors indicate that if banks disclose relevant information on their capital structure and their risk exposure, this would allow for an effective market discipline practice.

Similarly, Hall (2006) supported the proposals of the Basel Committee on strengthening market discipline at the regulatory level. The author confirmed that the third pillar of second Basel accord is needed to improve the bank's communication with the market. He insisted that communication should include information about risk exposure (credit, market, operational) and capital adequacy ratios by communicating qualitative information on internal rating systems and assessment of capital adequacy ratios. Moreover, Landskroner and Paroush (2008) believe that market discipline as stipulated by the third pillar of the second Basel accord provides a mechanism that replaces government intervention. Stephanou (2010) adds that market discipline can also operate via regulatory intervention triggered by market signals, such as price movements of banking securities.

Freixas and Laux (2012) and Mehran and Mollineaux (2012) explain that access to information is a necessary condition for transparency. However, transparency depends on the active efforts of information receivers as dictated by their incentives to gather, interpret and impound available information into their decision-making processes. Tadesse (2006) studied the relationship between stability of the banking sector and economic consequences of banks' regulated communication. The author showed that banking communication has positive effects on the stability of the banking sector.

Nier and Baumann (2006) showed that market discipline is an effective mechanism to encourage banks to reduce their default risk, by holding a regulatory safety cushion. However, they indicate that market discipline remains limited in a country where governmental support is high. They also assume that market discipline will be more efficient when competition is strong, since this latter leads to a higher risk-taking. Nier and Bauman (2006) examined the relationship between transparency and risk by using three different information disclosure indices. The first index indicates that if a bank is listed on the NYSE, the NASDAQ or on the AMEX, it should align itself with limiting information disclosure rules imposed by the market. The second index uses a bank's rate attributed by an internationally recognized rating agency like standard and Poor's, Moody's or Fitchrating. The third index measures voluntary disclosure of financial information. This index is constructed by 17 information categories disclosed by the bank and treats one or more dimensions of the risk profile. Each category is represented by a sub-index that measures accounting information details that banks disclose in their annual reports. This index is a direct measure of information quantity communicated to the market.

The results of Nier and Bauman (2006) show that when banks choose to voluntarily disclose more information to market operators, they subsequently choose to improve their solvency either by reducing their risk-taking or improving risk coverage by equity. Then, we can assume that the higher the extent of voluntary disclosure of 
financial information in a given year is, the lower risk-taking in the year that follows will be.

\section{Other Factors Affecting Risk Level in Banks}

To better understand the impact of transparency on Tunisian banks' fragility, we include in our empirical analysis several other variables deemed relevant by the literature to explain banks' risk level. We present in the following the literature review on the relationship between these factors and risk-taking by banks.

\subsection{The Capital Adequacy Ratio}

The literature examining the relationship between risk-taking and capital ratio reached conflicting results. To respect the minimum ratios required by regulatory capital, banks may pursue several strategies. They can either increase equity or shift their investments towards assets considered less risky or decrease total assets by having recourse to securitization.

Kahane (1977), Koehn and Santomero (1980) and Kim and Santomero (1988) used portfolio theory to explain the relationship between risk and regulatory capital. These authors found that capital ratio transforms banking investment efficiency. Thus, the bank could respond by restructuring its asset portfolio, which depends on the degree of risk aversion. Then, portfolio theory pointed to the possible perverse effects of regulatory capital, showing that, contrary to the initial objective of reducing default risk, a capital constraint can lead to an increase in the likelihood of bank bankruptcy.

Furlong and Keeley (1989) questioned the results of Kim and Santomero (1988). Taking into account the existence of deposit insurance, they showed that an unregulated bank might increase risk-taking to maximize the value of its shares at the expense of deposit insurance. The introduction of the concept of regulatory capital could negatively influence these incentives, forcing shareholders to suffer more losses because of excessive risk-taking. They argue that regulation has a stabilizing effect as it reduces risk of bank insolvency.

Such conflicting results on capital ratio, suggests undertaking more empirical research. Most authors explained the evolution of risk and capital using the partial adjustment model. Following the implementation of the leverage ratio by US banks, Shrieves and Dahl (1992) have been the first to examine this relationship. They found that changes in capital affect positively risk level because banks try to offset capital increase by greater risk-taking. Wachtel and Haubrich (1993) studied whether changes in a banking portfolio composition can be explained by the new capital standard. Their findings show that implementing the first Basel accord pushed under-capitalized banks to recompose their portfolios using less risky assets.

Using the same methodology of Shrieves and Dahl (1992), Jacques and Nigro (1997) found that the imposition of risk weighted capital ratio led to an important rise in capital and an important decrease in risk exposure by banks. Moreover, Aggarwal and Jacques (1998) found that both under-capitalized banks and capitalized banks increased their capital ratios and reduced risk.

Karels et al. (1989) used a univariate analysis of 24 Taiwanese banks over the period 1997-1984. They found that when capital requirements are high, risk level is low. Rime (2001) examined capital adjustment for Swiss banks when this latter is closer to the regulatory minimum. Their study is quite important because regulatory pressure in Switzerland is stronger than in other countries. It seems that Swiss banks try to quickly reach the ratios required by law to avoid several punishments provided for by regulation. Concerning regulatory pressure, it seems to be more important for undercapitalized banks than for others. This pressure has a positive and a significant impact on the capital adequacy ratio, but it does not influence the bank's risk-taking. This means that banking firms do not reduce their risk-taking, but they choose to increase their capital adequacy ratios by increasing their equity either by issuing new shares or by retaining profits.

However, in a dynamic framework, the results of Calem and Rob (1999) mitigated the previous results. They found that risk taking by banks depends on their capital ratios and the relationship between risk level and capital level follows a U-shaped curve. The share of risky assets is very higher for undercapitalized banks. This reflects the presence of a moral hazard behavior in these banks. Gradually, as capital increases, risk-taking declines. Thereafter, believing that bankruptcy risk is too low, well-capitalized banks increase their risk-taking.

Finally, according to this literature review, theoretical as well as empirical, we notice that there is no consensus on the relationship between capital regulation and risk-taking for banks. It is therefore useful to examine the effect of this regulation for each context and for each country.

In this study, we support the hypothesis which states that when bank capital is high, risk-taking for banks is low. Therefore, we expect a negative relationship between the capital adequacy ratio and risk-taking for Tunisian banks. 


\subsection{The Bank's Portfolio Quality}

The main factors explaining deterioration of banking profitability and the increase in banking fragility relate to a deterioration of assets quality through an accumulation of bad loans (Demirguc-Kunt, 1989; Berger \& DeYoung, 1997).

The classic function of banks, namely collecting deposits and granting loans, remains the main function of these institutions, mainly in developing countries. Loans given by banks are an important source of income. However, the relationship between the rate of credits granted and the bank's profitability depends on their risk. Gradually, as credit risk increases, the return required by the bank increases. However, when the failure rate of these loans is high, the bank's losses would be very big, which would negatively affect its profitability. Therefore, insolvency risk of the bank increases (Caudamine \& Montier, 1998). We assume then that a bad credit portfolio quality is associated with a greater insolvency risk.

\subsection{Liquidity}

The more the bank provides credits, the more it has an important market share, thus its performance improves and failure risk diminishes. The granting of credits depends particularly on the bank's ability to collect deposits.

However, the massive use of credit financed by deposits expose the bank to a higher liquidity risk, which could degenerate into an insolvency risk in the case of a trust crisis and a massive withdrawal of deposits. Furthermore, when the bank's deposits are important, the moral hazard problem could increase because of implicit deposit insurance and could encourage managers to take excessive risk.

Almeras and HadjKacem (2006) conducted a study that focused on Maghreb Banks (Moroccan, Algerian and Tunisian banks). They found that liquidity is abundant in the composition of the balance sheet of these banks, stating: "In North Africa, banks face a considerable re-employment problem of the funds they collect ... As in many other developing countries, Maghreb banks are structurally over-liquid, but their resources are absorbed by government securities in the short term yet they have insufficient liquidity to support economic development ... ". Therefore, we expect a positive relationship between liquidity and risk level of Tunisian banks. The more the bank has liquid assets, the more it is badly managed, then the higher risk level is.

\subsection{Managerial Efficiency}

Barr and Siems (1996) state that management quality of a bank is the key to its long-term performance and sustainability. They explain that the main challenge for managers is to adapt to the changing environment of uncertainty and risks. On the one hand, this means that bankers should allocate scarce resources, implement control procedures to minimize risks and control costs and should be able to adopt new technologies to improve the bank's operational efficiency. On the other hand, managers should readily accommodate the new regulatory actions, they should have the necessary skills to cope with economic fluctuations, technological developments and structural changes in the global economy.

The impact of management quality on performance and on banking failure has long been widely studied. Kaufman (1986) argues that to survive in a dangerous world banking firms should accept and manage risk well. Risk management seems to be the most important factor in banking failures. Booker (1983) states that mismanagement and risky strategies are the main factors that undermine the functioning of the bank. Cates (1985) clarifies that banking failure, which affects only a small number of banks, mainly results from a bad management of traditional banking risks, such as credit and liquidity risks. Bovenzi et al (1985) suggest that poor management is the main factor that explains why a bank survives while another fails in similar circumstances. Pantalone and Platt (1987) also indicate that it is management efficiency of the bank that determines its success or its failure. Similarly, Looney et al. (1989) state that management incompetence is one of the main reasons of banking failure.

To take into account the marginal effect of management quality on the insolvency risk of Tunisian banks, we use the ratio total banking expenses / total banking income. In fact, poor management "Bad management" may suggest a limited control over both the operating costs and the quality of credits granted to customers (Berger \& DeYoung, 1997). Therefore, these operating costs will be relatively high compared to other banks whose management quality is better. Moreover, returns will be lower compared to those of other banks.

Consequently, we can conclude that the ratio is low when management quality is better. However, in the case of good management, banking performance would be better and the bank's insolvency risk would be lower. Banks that operate more efficiently than others accumulate higher profits and have a lower insolvency risk. Therefore we expect a negative relationship between this ratio and the bank's insolvency risk. 
However, banks may witness an increase in operating expenses because of exogenous factors that lead to an accumulation of bad loans and therefore negatively affect profitability. Berger and DeYoung (1997) describe this as "Bad luck". Banks may then incur additional costs to deal with bad loans by using procedures that aim at a better selection of investment projects. Under this hypothesis, we expect a negative relationship between management quality index and banking risk. When the bank incurs additional expenses in order to better control and supervise the function of granting loans and to recover the accumulated bad loans because of exogenous factors, bank performance would be higher and insolvency risk would be lower.

\subsection{Franchise Value}

Guttentag and Herring (1983) define franchise value as "the present value of the net income the bank would be expected to earn on new business if it were to retain only its office, employees, and customers. (...) [It] depends on the bank's authorized powers, including power to do business within specified areas, the market structure in the area, the expertise of the bank's employees, and the customer relationship it has developed".

In this view, franchise value is defined as the present value of the future profits that a bank is expected to earn from its access to protected markets, its reputation, economies of scale and superior information in financial markets. It is an intangible asset, which would be foregone if the bank goes bankrupt or is closed by authorities.

As specified by Demsetz, Saidenberg and Strahan (1996), franchise value is the result of two main sources. First, market regulation, which by limiting competition provides a market power to banks operating in regulated markets. In almost all countries around the world, the banking industry is highly regulated (Benston, 1983). Entry in the banking sector is subject to obtaining a right to operate granted by the authorities. Hence, franchise value largely depends on the number of banks allowed in the system, which in turn depends on entry costs and required capital levels (Milne \& Whaley, 1998). Second, the nature of banking activities can influence banks to increase franchise value. This latter relates to bank's reputation, which generates a favorable business framework with partners and from its unique lending relationship with its customers. Through long-term lending relationships with these customers banks have access to private information that is not available on financial markets. This helps them to reduce the cost of loan origination, making lending activities more profitable.

Several theoretical and empirical studies argue that banks with a high franchise value do not undertake highly risky investment projects. In a purely theoretical work, Marcus (1984) showed that when franchise value is high, shareholders' moral hazard behavior decreases. In fact, because of a defect caused by a risky strategy, the losses the bank can endure in terms of share value would be greater than the gain generated by such a policy. Therefore, we expect a negative relationship between the bank's franchise value and its risk level.

\subsection{Bank Size}

Kwan (2003) found that bank size has a positive and a significant effect on its profitability suggesting the relevance of economies of scale. In addition, large banks are supposed to have lower risk because of their ability to hold more diversified portfolios. Similarly, large banks have easier access to capital markets, allowing them to adapt quickly to lack of capital or liquidity. Referring to these arguments, we can conclude that bank size could negatively relate to insolvency risk.

Moreover, banking regulation imposes some discipline on banks' risky behavior. However, this discipline is imperfect for large banks. Indeed, failure of large banks could lead to very high costs, and therefore they generally anticipate no regulatory intervention. Their expectation of no intervention stems from the "too big to fail" principle and the problem of waiting (Kane, 1989). Indeed, such problems can lead banks to engage in excessive risky activities. Against these arguments, we expect a significant and a positive impact of bank size and bank insolvency risk.

\subsection{Ownership Structure}

Economics literature explains that the presence of public banks reflects the inadequacies of the financial and credit markets (Stiglitz \& Weiss, 1981). Therefore, creation of public banks responds to the fact that private banks do not finance fragile and highly risky sectors because they do not take into consideration social returns in their funding decisions. Public banks are therefore an engine of economic and social welfare development (Stiglitz, 1993), but they incur a high risk level. Therefore, we expect a positive relationship between the bank's public ownership share and its risk level.

Similarly, it is important to study the impact of foreign ownership on banks' risk level. Foreign banks are large and have the opportunity to enter capital markets and are able to diversify risk (Bonin et al., 2005). We assume, therefore, that there is a negative relationship between foreign ownership and risk of Tunisian banks. 


\section{Impact of Financial Information Voluntary Disclosure on the Fragility of Tunisian Banks: An Empirical Analysis}

This section presents the methodology used to examine the effect of transparency on the fragility of Tunisian banks. We present first our measurement tools. Then, we present the descriptive statistics. Finally, we present the results of the multivariate regressions we used. The dependent variable is the non-performing loans rate.

\subsection{Measurement of the Dependent Variable}

To apprehend the fragility of the Tunisian banking sector, we use as measure the non-performing loans rate. This is the amount of bad loans reported to total loans (PNPCR). This represents one of the first quantitative indicators of a deteriorating credit portfolio quality. This is the best measure of credit risk, which is the most important reason behind fragility of Tunisian banks.

\subsection{Measurement of the Independent Variables}

To test the effect of voluntary disclosure of financial information (DISCL) on the fragility of Tunisian banks, we use as a predictor a voluntary disclosure of financial information index published in the annual activity reports of Tunisian banks. Referring to the study of Nier and Baumann (2006) we identified 17 items. These items relate to financial information disclosed differently by Tunisian banks in their annual reports. Some banks publish this information in detail. However, other banks are reluctant to communicate this information with no reasons given. We present in Table 1 below, detailed information on the 17 items retained to construct the disclosure index.

We start by reading annual reports and we ascribe to each item either the value of 1 , or the value of 0 . We assign the value of 1 if information about this item is well detailed in the bank's annual activity report (the $3^{\text {rd }}$ column of the Table 1). If no detail exists in the annual activity, we assign to this item the value of 0 .

Table 1. Presentation of items retained for the construction of the voluntary disclosure index of Tunisian banks over the period 2000-2011

\begin{tabular}{|c|c|c|}
\hline Sub-index & Items & Categories \\
\hline \multicolumn{3}{|c|}{ Assets } \\
\hline \multirow[t]{5}{*}{ Loans } & S1 : Loans by maturity & $\begin{array}{l}\text { Loans and advances ( } 3 \text { months, loans and advances 3-12 months, } \\
\text { loans and advances } 1 \text { year) }\end{array}$ \\
\hline & S2 : Loans by counterparty & Loans to group companies, loans to other corporate, loans to banks \\
\hline & S3 : Problem loans & Total problem banks \\
\hline & S4 : Problem loans by type & Overdue/ restructured/ other non-performing loans \\
\hline & S5 : Risk weighted assets & Total of risk weighted assets \\
\hline \multirow[t]{2}{*}{$\begin{array}{l}\text { Other } \\
\text { assets }\end{array}$} & S6 : Securities by type & $\begin{array}{l}\text { Treasury bills, other bills, bonds, CDs, equity investments, other } \\
\text { investments }\end{array}$ \\
\hline & S7 : Securities by holding purpose & Investments, trading \\
\hline \multicolumn{3}{|c|}{ Liabilities } \\
\hline \multirow[t]{2}{*}{ Deposits } & S8 : Deposits by maturity & $\begin{array}{l}\text { Demand, saving, sub } 3 \text { months, 3-6 months, } 6 \text { months-1 year, 1-5 } \\
\text { years, }\end{array}$ \\
\hline & S9 : Deposits by maturity & Banks/customers/municipal, goverment \\
\hline \multirow[t]{2}{*}{ Other funding } & S10 : Money Market funding & Total money market funding \\
\hline & S11 : Long-term funding & $\begin{array}{l}\text { Convertible bonds, mortgage bonds, other bonds, subordinated } \\
\text { debt, hybrid capital }\end{array}$ \\
\hline \multicolumn{3}{|c|}{ Income statement } \\
\hline & S12: Non interest income & Net commission income, net fee income, net trading income \\
\hline & S13: Loan loss provisions & Total loan loss provisions \\
\hline \multicolumn{3}{|c|}{ Memo lines } \\
\hline & S14 : Reserves & Loan loss reserves (memo) \\
\hline & S15 : Capital & Total capital ratio, Tier 1 ratio, total capital \\
\hline & S16 : Off-balance sheet (OBS) items & OBS items \\
\hline & S17 : Liquid assets & Total liquid assets \\
\hline
\end{tabular}

To determine the global index of voluntary disclosure of Tunisian banks, we calculate the mean of the values obtained on the17items using the following formula: 


$$
\operatorname{DISCL}_{i, j}=\sum_{i=1}^{17} \frac{I_{i, j}}{17}
$$

Where,

DISCL $_{i, j}$ is the global index of voluntary disclosure of the year (i) of the bank (j);

$I_{i, j}$ represents the items forming the global disclosure index

Moreover, to determine the effect of the capital adequacy ratio (CAR) on risk level, we use the capital adequacy ratio as calculated by the Central Bank of Tunisia in compliance with the international standards of Basel I. We use a lag of one year for the capital ratio $\left(\mathrm{CAR}_{\mathrm{t}-1}\right)$ to capture the effect of the capital adequacy ratio on risk level and not the reverse.

We measure liquidity (LIQU) by the ratio of loans granted to customers reported to customer deposits. Management efficiency (EFFIC) is measured by the ratio of the bank's total operating expenses reported to the bank's total revenues. The bank's operating expenses include accrued interest and related expenses, incurred commissions and losses on commercial securities and financial operations; revenues consist in interest and similar income, commissions on products, gains on commercial securities and financial operations and income from investment portfolio.

To control the effect of ownership structure on risk level of Tunisian banks, we use public ownership (POWN) and foreign ownership (FOWN) share percentages.

The effect of franchise value on Tunisian banks' insolvency risk is tested by introducing in the regression the variable $\left(\mathrm{FRANCH}_{\mathrm{t}-1}\right)$ which measures the difference between market value and book value of assets. This difference is reflected in the difference between book value of equity and the value fixed by investors in the financial market. A lag of one year is intended to capture the effect of franchise value on risk level and not the reverse. The variable (FRANCH) is measured by the ratio (liabilities book value + equity market value) / assets book value. We expect a negative relationship between this variable and the bank's insolvency risk.

Finally, the measure used to apprehend the bank size (SIZE) is the natural logarithm of total assets.

\subsection{Specification of the Empirical Model}

The model takes the following matrix:

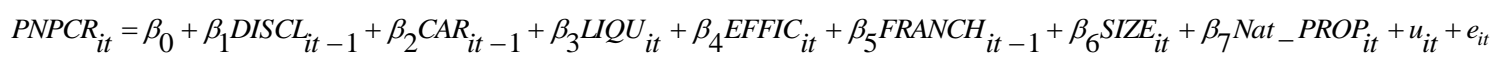

Where,

$\mathrm{i}=1 ; 2 ; \ldots ; 10 \quad \mathrm{n}=10 \quad$ (banks)

$\mathrm{t}=2000 ; \ldots ; 2011 \quad \mathrm{t}=12 \quad$ (years)

$u_{i t}$ represents a specific effect to each bank, which remains constant over time, while $e_{i t}$ is a random disturbance.

\subsection{Sample and Descriptive Statistics}

Data used in the empirical analysis are taken from the financial statements of the ten banks listed on the Securities Stock Exchange of Tunis (BVMT) during the period 2000-2011. We retained 10 listed banks. We have paid particular attention to the continuity of banks' temporal data. Information about the capital adequacy ratio is obtained from the Central Bank of Tunisia's database. All the other information is collected from the banks' annual activities reports.

Descriptive statistics presented below show that the capital adequacy ratio differs across banks. On average, this ratio is equal to $10.28 \%$. However, for the bank with the lowest capitalization, this ratio $0.4 \%$, while for the most capitalized bank this ratio is $22.1 \%$.

Similarly, we notice that the financial variables representing portfolio quality, liquidity, management quality and franchise value differ significantly. Difference in the results reflects a considerable difference in the behavior of Tunisian banks. Hence the importance of examining the impact of these factors on risk level of these banks. 
Table 2. Descriptive statistics of the variables (number of observations $=120$ )

\begin{tabular}{lllll}
\hline Variables & Mean & St-dev & Min & Max \\
\hline PNPCR & 19.825 & 12.660 & 5.08 & 56.940 \\
CAR & 10.285 & 4.030 & .0461 & 22.1 \\
DISCL & 0.5848 & 0.287 & 0 & 1 \\
LIQU & 103.18 & 20.139 & 54.18 & 146.87 \\
EFFIC & 39.564 & 7.3982 & 25.97 & 53.800 \\
FRANCH & 100.42 & 7.9288 & 84.42 & 149.67 \\
SIZE & 14.512 & 0.5011 & 13.53 & 15.445 \\
POWN & 22.479 & 27.316 & 0 & 68.4 \\
FOWN & 24.782 & 22.780 & 0 & 64.2 \\
\hline
\end{tabular}

PNPCR is the non-performing loans rate; DISCL is the global index of voluntary disclosure; CAR is the capital adequacy ratio as calculated by the Central Bank of Tunisia; LIQU is the ratio of loans granted to customers reported to customer deposits; EFFIC is measured by the ratio of the bank's total operating expenses reported to the bank's total revenues; POWN is the percentage of public ownership; FOWN is the percentage of foreign ownership; FRANCH is measured by the ratio (liabilities book value + equity market value) / assets book value; SIZE is the natural logarithm of total assets.

\subsection{Regressions Analysis}

As mentioned above, we examined10 banks and time series over 12 years. Baltagi (2001) and Hsiao (1986) indicate that Panel data methodology controls individual heterogeneity, reduces multicollinearity and biased estimation problems. Estimation by ordinary least squares (OLS) on a panel data presupposes uniformity in the sample, otherwise the estimators are biased.

Heterogeneity of the means of the independent variables and their standard deviations across the different banks in our sample show the need for other tests in order to choose the appropriate estimator.

In conducting the Fisher (F-test) and the Breushe-Pagan Lagrange Multiplier (LM) tests, we accept the rejection of a homogeneous Panel and therefore our model is either with fixed effects or with random effects. The Hausman test (1968) tells us that the model that fits the data structure of the sample is a fixed effects model.

Estimating a fixed effect model helps to eliminate heterogeneity and to use OLS on transformed data. Indeed, applying this model relates to calculating for each variable its deviation from the mean of the period for each bank (WITHIN processing). However, calculating the estimate eliminates any variable that does not vary in time for the same bank, like the variables that take 0 or 1 (the variables representing private ownership and duality in our study).

In addition, the data presents problems of heteroscedasticity, cross-sectional correlation and first-order autoregressive correlation $\mathrm{AR}(1)$ in the error terms.

The FGLS and PraisWinsten Regression (PCSE) methods can overcome these problems. These methods allow for estimating the presence of $\mathrm{AR}(1)$ autocorrelation within panels and cross-sectional correlation and heteroscedasticity across panels. These methods can also estimate the coefficients of the variables that do not vary in time for the same bank.

In interpreting the results, we retain those obtained by the PCSE method. The latter method gives, in fact, more robust and more reliable results than those provided by the FGLS method. Beck and Katz (1995) showed that the FGLS method gives biased results. This bias mainly relates to an underestimation of the standard errors of the regression parameters. The PCSE method retains the parameters estimated by the ordinary least squares (OLS) by considering the standard errors as biased. Then, these biased standard errors are replaced by new standard errors (panel-corrected standard errors or PCSE) obtained after taking into account temporal and spatial autocorrelations.

Moreover, the data shows a strong collinearity between public and private ownership variables. To avoid bias, we included these two variables separately in the regression model.

We report the results of the FGLS method and those of the PCSE method in Table 3 below.

The results obtained show that:

The extent of voluntary disclosure of financial information in a given year has no effect on credit portfolio quality (PNPCR) of the following year. This result invalidates the result obtained by Nier and Baumann (2006) who conclude that banks that choose to pursue an extended strategy of voluntary disclosure of financial 
information would be required thereafter to reduce their risk exposure. Because by choosing to disclose their risk profiles, banks can be penalized by investors if the chosen risk is high. Similarly, this result invalidates the predictions of the third pillar of the second Basel Committee accord, which specifies that better disclosure is an important precondition for the functioning of market discipline.

Regarding the capital adequacy ratio, the results show that it has no effect on Tunisian banks' risk-taking as measured by the non-performing loan rate (PNPCR). This result shows that the recommendations of the Basel Committee, which consist in imposing a minimum capital ratio, may not ensure the stability of the Tunisian banking system.

Moreover, management efficiency (EFFIC) measured by the ratio of operating expense reported to operating income, has a positive and a statistically significant effect on the non-performing loans rate (PNPCR). This may suggest that the least efficient banks are those with large bad loans. This is consistent with the predictions of Berger and DeYoung (1997) explaining that bad management can be explained by a light control on both the operating costs and credits quality.

The results also indicate that franchise value $\left(\mathrm{FRANCH}_{\mathrm{t}-1}\right)$ has a negative and a statistically significant effect on the non-performing loans rate. This result confirms the theoretical findings of Marcus (1984) who argues that banks with a high franchise value reduce their risk-taking. We can conclude that with a strong franchise value, shareholders' moral hazard behavior decreases. With excessive risk-taking and in case of default, loss for shareholders in terms of share value would be greater than profits generated by excessive risk-taking. Therefore, shareholders have an interest in making sure that managers reduce their risk-taking.

As for bank size (SIZE), the results indicate its effect on the non-performing loan rate (PNPCR) is negative and statistically significant. It therefore seems that large banks are less exposed to credit risk. This result joins that of Hu et al. (2004). Large banks have in fact sufficient resources which allow them to better select their customers and to better treat defaulting creditors. However, small banks are exposed to a higher pressure to create income, and then they may grant credits to bad borrowers. Moreover, they are exposed to the adverse selection problem because of lack of experience and competences that prevents them from effectively assessing the credit worthiness of their customers.

Table 3. Panel data regressions of the non performing loans on the extent of voluntary disclosure of financial information of Tunisian banks over the period 2000-2010

\begin{tabular}{|c|c|c|c|c|}
\hline \multirow[b]{2}{*}{ VARIABLES } & \multicolumn{2}{|c|}{ Model I (FGLS) } & \multicolumn{2}{|c|}{ Model II (PCSE) } \\
\hline & PNPCR & PNPCR & PNPCR & PNPCR \\
\hline \multirow[t]{2}{*}{ TRANSP $_{\mathrm{t}-1}$} & -0.00245 & $-0.00958^{*}$ & -0.00512 & -0.0202 \\
\hline & $(0.00339)$ & $(0.00557)$ & $(0.0428)$ & $(0.0438)$ \\
\hline \multirow[t]{2}{*}{$\mathrm{CAR}_{\mathrm{t}-1}$} & -0.0250 & $-0.0808 * *$ & -0.0186 & -0.0396 \\
\hline & $(0.0243)$ & $(0.0331)$ & $(0.343)$ & $(0.347)$ \\
\hline \multirow[t]{2}{*}{ LIQU } & $-0.0357 * * *$ & $-0.0113^{* *}$ & -0.0363 & -0.00923 \\
\hline & $(0.00239)$ & $(0.00473)$ & $(0.0376)$ & $(0.0415)$ \\
\hline \multirow[t]{2}{*}{ EFFIC } & $0.428 * * *$ & $0.448 * * *$ & $0.450^{* *}$ & $0.460 * *$ \\
\hline & $(0.0130)$ & $(0.0239)$ & $(0.201)$ & $(0.207)$ \\
\hline \multirow[t]{2}{*}{$\mathrm{FRANCH}_{\mathrm{t}-1}$} & $-0.409 * * *$ & $-0.524 * * *$ & $-0.419 * * *$ & $-0.529 * * *$ \\
\hline & $(0.0129)$ & $(0.0181)$ & $(0.141)$ & $(0.136)$ \\
\hline \multirow[t]{2}{*}{ SIZE } & $-9.648 * * *$ & $-7.242 * * *$ & $-9.160 * *$ & $-6.393^{*}$ \\
\hline & $(0.356)$ & $(0.462)$ & $(3.814)$ & $(3.442)$ \\
\hline \multirow[t]{2}{*}{ POWN } & $0.119 * * *$ & & 0.128 & \\
\hline & $(0.00688)$ & & $(0.0996)$ & \\
\hline \multirow[t]{2}{*}{ FOWN } & & $0.0283^{* * *} *$ & & 0.0375 \\
\hline & & $(0.00851)$ & & $(0.110)$ \\
\hline \multirow[t]{2}{*}{ Constant } & $188.5^{* * *}$ & $164.0^{* * *}$ & $181.7 * * *$ & $151.5^{* * *}$ \\
\hline & $(5.942)$ & $(7.370)$ & $(56.46)$ & $(55.30)$ \\
\hline Observations & 120 & 120 & 120 & 120 \\
\hline R-squared & & & 0.568 & 0.546 \\
\hline Number of banks & 10 & 10 & 10 & 10 \\
\hline
\end{tabular}

Reported in parentheses are standard errors.

*** Significant at $1 \%$ level, $* *$ significant at $5 \%$ level and $*$ significant at $10 \%$ level. 
PNPCR is the non-performing loans rate; DISCL is the global index of voluntary disclosure; CAR is the capital adequacy ratio as calculated by the Central Bank of Tunisia; LIQU is the ratio of loans granted to customers reported to customer deposits; EFFIC is measured by the ratio of the bank's total operating expenses reported to the bank's total revenues; POWN is the percentage of public ownership; FOWN is the percentage of foreign ownership; FRANCH is measured by the ratio (liabilities book value + equity market value) / assets book value; SIZE is the natural logarithm of total assets.

\subsection{Robustness}

The Tunisian economy has known in 2011 unprecedented difficulties resulting from the revolution and the country's political instability. The repercussions of this revolution have been exacerbated by economic and financial crises and sovereign debt crisis in Europe, which is the first economic partner of Tunisia. This without doubt negatively affected the Tunisian economy, in particular the financial strength of the Tunisian banking system.

It is therefore necessary to check the robustness of the results by omitting the 2011 year from the regression analysis. Table 4 below reports the results of the regression after deleting the year 2011 from the analysis. The results obtained over the period 2000-2010 are consistent with those obtained over the period 2000-2011.

Table 4. Panel data regressions of the non performing loans on the extent of voluntary disclosure of financial information of Tunisian banks over the period 2000-2011

\begin{tabular}{lcc}
\hline VARIABLES & PNPCR & PNPCR \\
\hline TRANSP $_{\mathrm{t}-1}$ & -0.00093 & -0.0213 \\
CAR $_{\mathrm{t}-1}$ & $(0.0459)$ & $(0.0476)$ \\
& 0.0428 & $(0.448)$ \\
PNPCR & $(0.447)$ & -0.0122 \\
LIQU & & $(0.0453)$ \\
& -0.0416 & $0.474^{* *}$ \\
EFFIC & $(0.0423)$ & $(0.228)$ \\
& $0.470^{* * *}$ & $-0.538^{* * *}$ \\
FRANCH & $(0.225)$ & $(0.152)$ \\
SIZE & $-0.425^{* * *}$ & $-6.572^{*}$ \\
POWN & $(0.156)$ & $(3.853)$ \\
FOWN & $-9.829 * *$ & $(4.360)$ \\
Constant & 0.136 & 0.0355 \\
Observations & $(0.110)$ & $(0.117)$ \\
R-squared & & $154.1^{* *}$ \\
Number of banks & & $(63.52)$ \\
\hline
\end{tabular}

Reported in parentheses are standard errors.

*** Significant at $1 \%$ level, ** significant at $5 \%$ level and * significant at $10 \%$ level.

PNPCR is the non-performing loans rate; DISCL is the global index of voluntary disclosure; CAR is the capital adequacy ratio as calculated by the Central Bank of Tunisia; LIQU is the ratio of loans granted to customers reported to customer deposits; EFFIC is measured by the ratio of the bank's total operating expenses reported to the bank's total revenues; POWN is the percentage of public ownership; FOWN is the percentage of foreign ownership; FRANCH is measured by the ratio (liabilities book value + equity market value) / assets book value; SIZE is the natural logarithm of total assets.

\section{Conclusion}

This study examined the impact of voluntary disclosure of financial information on the fragility of Tunisian banks. We were motivated by the decision of the Central Bank of Tunisia to implement the directives of the 
second Basel Accord to improve the soundness and the safety of the banking system. We examined a sample of ten Tunisian banks listed on the Stock Exchange of Tunis, over the period 2000-2011. We used two estimation techniques; the Feasible Generalized Least Squares method and the PraisWinsten regression method. It has been proven that the latter method provides the most reliable and robust results.

The results show that voluntary disclosure of financial information in a given year has no effect on the non-performing loans rate of the following year. Similarly, the results show that the capital adequacy ratio of a given year has no effect on the non-performing loans rate of the following year. These results may undermine the effectiveness of the guidelines of the Basel Committee agreements to reduce risk-taking for Tunisian banks.

However, accumulation of bad loans by Tunisian banks is principally explained by endogenous factors. Management efficiency is, in fact, a key factor explaining the solidity of Tunisian banks. The least efficient Tunisian banks are those that suffer from a high rate of bad loans.

The obtained results may be of interest to bank managers and supervisory bodies to take necessary measures to reduce the degree of fragility of Tunisian banks. They should direct their efforts towards empowering administrators with regard to the importance of voluntary disclosure of financial information particularly with respect to risk profile. They should also reconsider prudential regulation by other measures that may have more effect on risk behavior of Tunisian banks. They can further enhance shareholder liability by applying the dual liability principle (Benston et al., 1986, Kane, 1989; Macey \& Miller, 1992). They can also strengthen the accountability of managers by encouraging manager ownership (Cole \& Mehran, 1998).

\section{References}

Aggarwal, R., \& Jacques, K. (1998). Assessing the impact of prompt corrective action on bank capital and risk. Federal Reserve Bank of New York Economic Policy Review, 4(3), 23-32. http://dx.doi.org/10.2139/ssrn.1024839

Almeras, G., \& Hadj, N. A. (2006). Rapport du Groupe de travail sur l'espace financier euro-méditerranéen. Institut de Prospective Economique du monde Méditerranéen. Paris, IPEMed.

Barr, R., \& Siems,T. (1996). Predicting bank failure using DEA to quantify management quality. Federal Reserve Bank of Dallas, Financial Industry Studies Working Paper, pp. 1-94. Retrieved from http://faculty.smu.edu/barr/pubs/bspredict.pdf

Benston, G. J. (1983). Federal regulation of banking. Journal of Bank Research, 13, 216-244.

Benston, G. J., Eisenbeis, R. A., Horvitz, P. M., Kane, E. J., \& Kaufman, G. G. (1986). Perspectives on safe and sound banking: Past, present, and future. Cambridge, Mass: MIT Press.

Berger, A. N., \& DeYoung, R. (1997). Problem Loans and Cost Efficiency in Commercial Banks. Journal of Banking and Finance, 21, 849-870. http://dx.doi.org/10.1016/S0378-4266(97)00003-4

Bliss, R. R., \& Flannery, M. J. (2002). Market Discipline in the Governance of U.S. Bank Holding Companies: Monitoring versus Influence. Review of Finance, 6(3), 361-396. http://dx.doi.org/10.1023/A:1022021430852

Bonin, J., Hasan, I., \& Wachtel P. (2005). Bank Performance, Efficiency and Ownership in Transition Countries. Journal of Banking and Finance, 29, 31-53. http://dx.doi.org/10.1016/j.jbankfin.2004.06.015

Booker, I. O. (1983). Tracking Banks from Afar: A Risk Monitoring System. Economic Review, November, $36-41$.

Bovenzi, J. F., \& Nejezchleb, L. (1985). Bank Failures: Why Are There So Many? Issues in Bank Regulation, 8 , 54-68.

Bushman, R. M. (2015). Transparency, Accounting Discretion and Bank Stability. Economic Policy Review, Forthcoming.

Calem, P., \& Rob, R. (1999). The impact of capital-based regulation on bank risk-taking. Journal of Financial Intermediation, 8, 317-352. http://dx.doi.org/10.1006/jfin.1999.0276

Cates, D. C. (1985). Bank Risk and Predicting Bank Failure. Issues in Bank Regulation, 16-20.

Caudamine, G., \& Montier, J. (1998). Banque et marchés financiers. Economica.

Cole, R. A., \& Mehran, H. (1998). The Effect of Changes in Ownership Structure on Performance: Evidence from the Thrift Industry. Journal of Financial Economics, 50(3), 291-317. http://dx.doi.org/10.2139/ssrn.7286 
Cordella, T., \& Yeyati, E. L. (1998). Public Disclosure and Bank Failures. International Monetary Fund Staff Papers, 45(1), March. http://dx.doi.org/10.2307/3867331

Demirguc-Kunt, A. (1989). Deposit-institution failures: A review of the empirical literature. Federal Reserve Bank of Cleveland. Economic Review, 2-18.

Demsetz, R. S., Saidenberg, M. R., \& Strahan, P. E. (1996). Banks with something to lose: The disciplinary role of franchise value. FRBNY Economic Policy Review, 1-14. http://dx.doi.org/10.2139/ssrn.1028769

Freixas, X., \& Laux C. (2012). Disclosure, transparency, and market discipline. In M. Dewatripont, \& X Freixas (Eds.), The crisis aftermath: New regulatory paradigms (pp. 69-104). London: Centre for Economic Policy Research. http://dx.doi.org/10.2139/ssrn.1964321

Furlong, F., \& Keeley, M. (1989). Capital regulation and bank risk-taking: A note. Journal of Banking and Finance, 13, 883-891. http://dx.doi.org/10.1016/0378-4266(89)90008-3

Giannetti, M. (2007). Financial liberalization and banking crises: The role of capital inflows and lack of transparency. Journal of Financial Intermediation, 16, 32-63. http://dx.doi.org/10.1016/j.jfi.2006.04.001

Guttentag, J., \& Herring, R. (1983). The Lender-of-Last-Resort Function in an International Context. Essays in International Finance, No. 151. Princeton: International Finance Section, Department of Economics, Princeton University.

Hall, M. J. B. (2006). Basel II: Panacea or a missed opportunity? Journal of Banking Regulation, 7, 106-132. http://dx.doi.org/10.1057/palgrave.jbr.2340008

Hamalainen, P., Hall, M., \& Howcroft, B. (2005). A Framework for Market Discipline in Bank Regulatory Design. Journal of Business Finance and Accounting, 32(1-2), 183-208.

Haubrich, J., \& Wachtel, P. (1993). Capital requirements and shifts in commercial bank portfolios. Federal Reserve Bank of Cleveland Economic Review, 29(Quarter 1), 1-15.

Hu, J. L., Li, Y., \& Chiu, Y. H. (2004). Ownership and nonperforming loans: Evidence from Taiwan's banks. The Developing Economies, 3, 405-420. http://dx.doi.org/10.1111/j.1746-1049.2004.tb00945.x

Jacques, K., \& Nigro, P. (1997). Risk-based capital, portfolio risk, and bank capital: A simultaneous equations $\begin{array}{lllll}\text { approach. Journal of Economics and Business, } & \text { 49, 533-547. }\end{array}$ http://dx.doi.org/10.1016/S0148-6195(97)00038-6

Kahane, Y. (1977). Capital adequacy and the regulation of financial intermediaries. Journal of Banking and Finance, 1, 207-218. http://dx.doi.org/10.1016/0378-4266(77)90007-3

Kane, E. J. (1989). The S\&L Insurance Mess: How Did It Happen? Washington, D.C.: Urban Institute Press, 1989.

Karels, G. V., Prakash, A. J., \& Roussakis, E. (1989). The Relationship between bank capital adequacy and market measures of risk. Journal of Business Finance and Accounting, 16, 663-673. http://dx.doi.org/10.1111/j.1468-5957.1989.tb00045.x

Kaufman, G. G. (1986). Banking Risk in Historical Perspective. Bank Structure and Competition, May, 231-249.

Kim, D., \& Santomero, A. (1988). Risk in Banking and Capital Regulation. The Journal of Finance, 43(5), 1219-1233. http://dx.doi.org/10.1111/j.1540-6261.1988.tb03966.x

Koehn, M., \& Santomero, A. (1980). Regulation of Bank Capital and Portfolio Risk. Journal of Finance, 35, 1235-1244. http://dx.doi.org/10.1111/j.1540-6261.1980.tb02206.x

Kwan, S. H. (2003). Operating Performance of Banks among Asian Economies: An international and Time Series Comparison. Journal of Banking and Finance, 27, 471-489. http://dx.doi.org/10.1016/S0378-4266(02)00384-9

Landskroner, Y., \& Paroush, J. (2008). Liquidity Risk and Competition in Banking. New York University, Working Paper. Retrieved from http://papers.ssrn.com/sol3/papers.cfm?abstract_id=1293634

Looney, S. W.,Wansley, J. W., \& Lane, W. R. (1989). An Examination of Mis- classications with Bank Failure Prediction Models. Journal of Economics and Business, 41, 327-336.

Macey, J. R., \& Miller, G. P. (1992). Banking law and regulation. Boston: Little, Brown.

Marcus, A. J. (1984). Deregulation and bank financial policy. Journal of Banking and Finance, 8(4), 557-565.

Mehran, H., \& Mollineaux, L. (2012). Corporate Governance of Financial Institutions. Annual Review of 
Financial Economics, 4, 215-232. http://dx.doi.org/10.1146/annurev-financial-110311-101821

Milne, A., \& Whalley, A. E. (1998). Bank Capital and risk-taking. Working Paper, Bank of England, 1998. http://dx.doi.org/10.2139/ssrn.147550

Nier, E. W. (2005). Bank Stability and Transparency. Journal of Financial Stability, 1, 342-354. http://dx.doi.org/10.1016/j.jfs.2005.02.007

Nier, E. W., \& Baumann, U. (2006). Market Discipline, Disclosure and Moral Hazard in Banking. Journal of Financial Intermediation, 15, 332-361. http://dx.doi.org/10.1016/j.jfi.2006.03.001

Pantalone, C. C., \& Platt, M. B. (1987). Predicting Commercial Bank Failure since Deregulation. New England Economic Review, Jul/Aug, 37-47.

Rime, B. (2001). Capital requirements and bank behavior: Empirical evidence for Switzerland. Journal of Banking and Finance, 25, 789-805.

Shrieves, R., \& Dahl, D. (1992). The relationship between risk and capital at commercial banks. Journal of Banking and Finance, 16, 439-457. http://dx.doi.org/10.1016/0378-4266(92)90024-T

Stephanou, C. (2010). Rethinking Market Discipline in Banking: Lessons from the Financial Crisis. Policy Research Working Paper 5227, The World Bank. http://dx.doi.org/10.1596/1813-9450-5227

Stiglitz, J. (1993). Some Theoretical Aspects of the Privatization: Applications to Eastern Europe. In Mario B. L. Paganetto, \& E. S. Phelps (Eds.), Privatization Processes in Eastern Europe (pp. 179-204). New York: St. Martin's Press.

Stiglitz, J., \& Weiss, A. (1981). Credit rationing in markets with imperfectif information. American Economic Review, 71, 393-410.

Tadesse, S. (2006). The Economic Value of Regulated Disclosure: Evidence from the Banking Sector. Journal of Accounting and Public Policy, 25, 32-70. http://dx.doi.org/10.1016/j.jaccpubpol.2005.11.002

\section{Copyrights}

Copyright for this article is retained by the author(s), with first publication rights granted to the journal.

This is an open-access article distributed under the terms and conditions of the Creative Commons Attribution license (http://creativecommons.org/licenses/by/3.0/). 